\title{
Génvizsgálat Treacher Collins-szindrómában
}

\author{
Zsigmond Anna dr. ${ }^{1}$. Till Ágnes dr. ${ }^{1}$. Pintér Adrienn Lilla dr. ${ }^{1}$ \\ Maász Anita dr. ${ }^{1,2}$. Szabó András dr. ${ }^{1,2}$. Hadzsiev Kinga dr. ${ }^{1,2}$
}

${ }^{1}$ Pécsi Tudományegyetem, Általános Orvostudományi Kar, Klinikai Központ, Orvosi Genetikai Intézet, Pécs ${ }^{2}$ Pécsi Tudományegyetem, Szentágothai János Kutatóközpont, Pécs

\begin{abstract}
A Treacher Collins-szindróma a mandibulofacialis dysostosisok csoportjába tartozó kórkép. Főbb jellegzetességei a maxillaris és mandibularis dysostosis, az antimongoloid szemrések, az alsó szemhéj colobomája, illetve a vezetéses halláscsökkenés. A szindrómával járó tünetek egyénenként és családon belül is nagyon eltérőek lehetnek; legenyhébb formái csaknem észrevehetetlenek, míg a súlyosabb esetekben az életet veszélyeztető légúti szövődmények léphetnek fel. Hátterében az esetek döntő többségében a TCOFl-gén eltérései játszanak szerepet, mely eltérések autoszomális domináns módon öröklődnek. Esetbemutatásunk célja, hogy felhívjuk a figyelmet a genetikai vizsgálat elvégzésének fontosságára olyan, klinikailag jól felismerhető tünetegyüttes, mint a Treacher Collins-szindróma esetén. Bár a betegség a klinikai kép alapján diagnosztizálható, az ismétlődés kockázatát csak úgy tudjuk pontosan meghatározni, ha ismerjük a családtagok genotípusát. A bemutatott család több tagjánál kimutatható volt a TCOFl-gén mutációja, annak ellenére, hogy klinikai tünetük nem volt. A jelenség magyarázata az inkomplett penetrancia, azaz a hibás gén fenotípusosan nem kerül kifejeződésre.

Orv Hetil. 2020; 161(52): 2201-2205.
\end{abstract}

Kulcsszavak: Treacher Collins-szindróma, TCOFl-gén, autoszomális domináns, inkomplett penetrancia

\section{Gene testing in Treacher Collins syndrome}

Treacher Collins syndrome belongs to the group of mandibulofacial dysostoses. Its main features are maxillary and mandibular dysostosis, downward-slanting palpebral fissures, coloboma of the lower eyelid and conductive hearing loss. The symptoms associated with the syndrome can vary greatly from individual to individual and within the family. In its mildest form, the syndrome is almost imperceptible, and when severe, life-threatening respiratory complication can occur. TCOFl is the major gene involved with an autosomal dominant mode of inheritance. The purpose of our case study is to draw attention to the importance of performing genetic testing in a clinically recognizable disorder such as Treacher Collins syndrome. Although the disease can be diagnosed based on the clinical symptoms, the risk of recurrence can only be accurately determined if the genotype of the family members is known. Several members of the presented family had a mutation in the TCOFI gene despite having no clinical symptoms. The explanation for this phenomenon is incomplete penetrance, i.e., the defective gene is not expressed in the phenotype.

Keywords: Treacher Collins syndrome, TCOF1 gene, autosomal dominant, incomplete penetrance

Zsigmond A, Till Á, Pintér AL, Maász A, Szabó A, Hadzsiev K. [Gene testing in Treacher Collins syndrome]. Orv Hetil. 2020; 161(52): 2201-2205.

(Beékezett: 2020. június 9.; elfogadva: 2020. július 16.)

\section{Rövidítések}

$\mathrm{AD}$ = autoszomális domináns; $\mathrm{AR}=$ autoszomális recesszív; ddNTP $=$ (dideoxynucleotide triphosphate $)$ dideoxinukleotidtrifoszfát; EFOP = (Emberi Erőforrás Fejlesztési Operatív Program; EFTUD2 = elongation factor Tu GTP-binding domain-containing 2; GINOP = Gazdaságfejlesztési és Innováci- ós Operatív Program; mRNS = (messenger) hírvivő RNS; NGS $=$ (next-generation sequencing) újgenerációs szekvenálás; OMIM $=($ Online Mendelian Inheritance in Man $)$ a „Mendeli öröklődés emberben" projekt online adatbázisa; PCR = (polymerase chain reaction) polimeráz-láncreakció; $P O L R 1 B=$ RNA polymerase I subunit $\mathrm{B} ; P O L R I C=$ RNA polymerase I 
and III subunit C; POLRID = RNA polymerase I and III subunit $\mathrm{D} ; \mathrm{RNS}$ = ribonukleinsav; $\mathrm{rRNS}$ = riboszomális $\mathrm{RNS}$; $T C O F 1=$ treacle ribosome biogenesis factor $1 ;$ TCS $=$ Treacher Collins-szindróma; VEKOP = Versenyképes Közép-Magyarország Operatív Program

A Treacher Collins-szindróma (TCS) (OMIM 154 500) a mandibulofacialis dysostosisok heterogén csoportjába tartozó kórkép. Az arc csontjainak és egyéb szöveteinek hibás kialakulását az embrionális fejlődés 5 . és 8 . hete között az első és a második kopoltyúívből származó struktúrák kóros fejlődése okozza. A betegség Edward Treacher Collins londoni szemészről kapta a nevét, aki 1900-ban elsőként írta le ezt a rendellenességet [1]. A mandibulofacialis dysostosisok közül a TCS a leggyakoribb, becsült prevalenciája l : 50000 [2]. A szindrómával járó tünetek egyénenként és családon belül is nagyon eltérőek lehetnek; legenyhébb formái csaknem észrevehetetlenek, nem kerülnek diagnosztizálásra, a súlyosabb esetekben azonban az életet veszélyeztetô légúti szövődmények léphetnek fel. A legtöbb tünet szimmetrikus megjelenést mutat, és már születéskor felismerhető. Főbb jellegzetességei a maxilla zygomaticus ívének, valamint a mandibula hypoplasiája, melyek következményes lágyrész-deformációval járnak. A szemrések rendszerint antimongoloid lefutásúak, gyakori az alsó szemhéj colobomája, az alsó szemhéjon a szempillák hiányozhatnak [3]. Egyes betegeknél szokatlan, praeauricularis hajnövekedés figyelhető meg. A hallójáratok atresiája, illetve a hallócsontocskák hypoplasiája az esetek 40-50\%-ában a vezetéses halláscsökkenéshez vezet [4]. A fülkagylók kicsik és dysplasticusak. A betegekre jellemző a kifejezett micro- és retrognathia, kevésbé gyakori a szájpadhasadék, valamint a choanaatresia előfordulása. A garat és a gége anatómiai eltérései életveszélyes légúti tüneteket és táplálási nehézségeket okozhatnak. Az érintettek többnyire normálintellektussal rendelkeznek, néhány esetben - kiterjedt, több gént érintő deletiók esetén - leírtak értelmi elmaradást is [5]. Korábban úgy gondolták, hogy az arc, illetve a nyak eltérései izoláltak, egy átfogó tanulmány során azonban meglepó módon nagy arányban figyeltek meg veleszületett szívfejlődési rendellenességeket [2]. A betegség komoly pszichés megterhelést jelent az érintettek és családjuk számára.

A TCS genetikailag is heterogén kórkép, egyértelmú genotípus-fenotípus összefüggések nem ismertek. A kórkép kialakulásában az esetek legnagyobb hányadában, akár 90\%-ban a TCOFI- (treacle ribosome biogenesis factor l) gén eltérései játszanak szerepet, emellett leírták a POLRID- (RNA polymerase I and III subunit D), illetve a POLRIC-(RNA polymerase I and III subunit C) gén mutációit is $[6,7]$. A POLRID-mutációk rendszerint enyhébb fenotípussal járnak. A TCOFl-gén esetében az öröklődés módja autoszomális domináns (AD), míg a POLRIC-gén esetében autoszomális recesszív (AR). A POLRID-gén érintettsége esetén AD és AR öröklődésmenet is előfordulhat. Egy 2020. évi tanulmányban a POLRIB (RNA polymerase I subunit) patogén variánsait találták 6 , klinikailag Treacher Collinsszindrómás beteg esetében [8]. Az EFTUD2-(elongation factor Tu GTP-binding domain-containing 2) gén eltéréseit azonosították az úgynevezett Guion-Almeida-típus esetében, mely súlyos, progresszív microcephaliával, intellektuális elmaradással, choanaatresiával, szájpadhasadékkal, szívfejlődési rendellenességekkel, valamint oesophagusatresiával jár [9]. A TCS hátterében feltehetően egyéb gének is szerepet játszanak, hiszen számos, klinikai vizsgálattal diagnosztizált esetben nem sikerült kimutatni a fenti gének eltéréseit [2].

Bár a diagnózis a klinikai kép alapján a legtöbb esetben felállítható, tünetszegény esetekben az alapos klinikai vizsgálat mellett képalkotó vizsgálatok elvégzésére is szükség lehet. A klinikai diagnózis alátámasztásaként molekuláris genetikai vizsgálatokkal igazolhatók a fenti gének mutációi. A szindróma specifikus kezelésére jelenleg nincs lehetőség. A betegek megfelelő gondozása, tüneti kezelésük érdekében számos szakma (gyermekgyógyász, fül-orr-gégész, fogszakorvos, plasztikai sebész, audiológus, szemész, pszichológus, klinikai genetikus) szoros együttmúködésére van szükség.

\section{Esetismertetés}

A fiúbeteg a 39 éves mater III/3. zavartalan graviditásából a 39. gesztációs hétre, fenyegető hegszétválás miatt császármetszéssel, 3750 grammal, jó általános állapotban született. Két idősebb fiútestvére egészséges. Cardiorespiratoricus adaptációja zavartalanul zajlott. A születését követően észlelt arcdiszmorfia alapján felmerült a TCS gyanúja. A fül-orr-gégészeti vizsgálat mindkét oldali hallójárat atresiáját írta le. Alapos klinikai kivizsgálása során (szemészet, kardiológia, ortopédia, koponya- és hasi ultrahangvizsgálat) társuló fejlődési rendellenesség nem igazolódott.

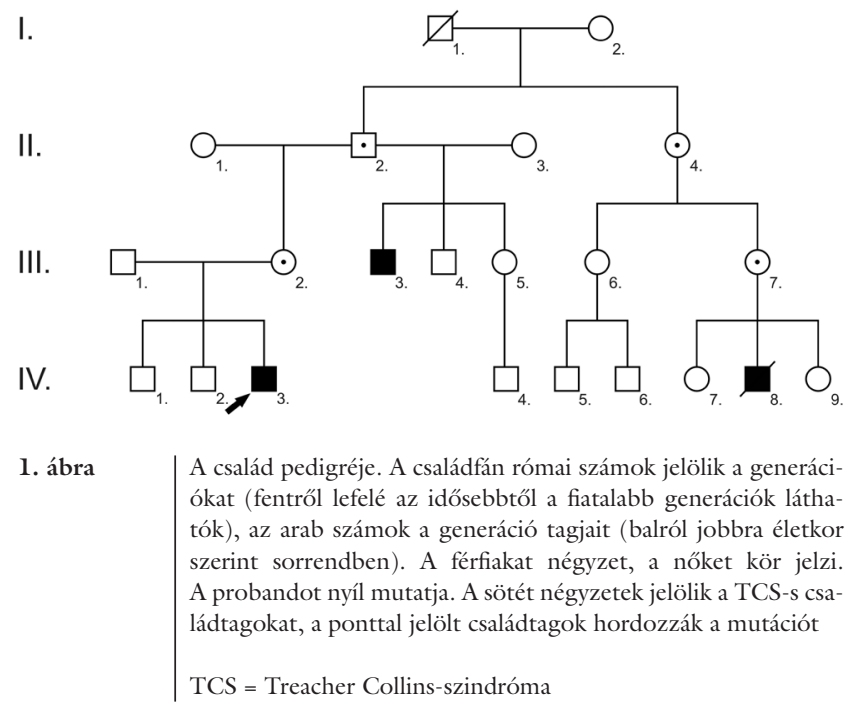




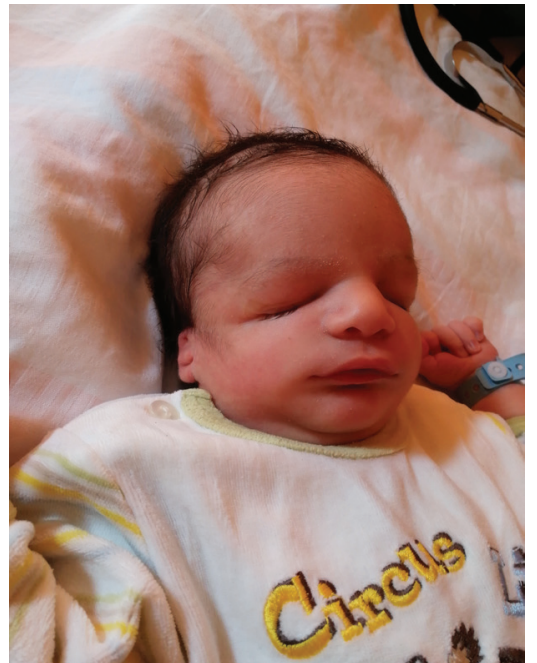

2. ábra

A proband újszülöttkorában (a fényképet a szülők engedélyével mutatjuk be)

A családi anamnézisből kiemelendő, hogy a mater apai ágú leány-unokatestvérének (III/7.) - betegünk születése előtt 15 évvel - klinikailag TCS-ás fiúgyermeke (IV/8.) született, aki kétéves korában aspiráció következtében exitált. Molekuláris genetikai vizsgálat akkor nem történt. A család pedigréjét az 1 ábra mutatja be.

A probandot félévesen vizsgáltuk először intézetünk genetikai tanácsadásán. A szindrómára jellegzetes, informatív morfogenetikai variánsokat (antimongoloid szemrés, befelé fordult alsó szemhéjak, lapos orrgyök, alacsonyan ülő fülek, deformált, fejletlen fülkagylók, hiányzó külső hallójáratok, lenőtt nyelv, gótikus szájpad, uvula bifida, retro- és micrognathia) észleltünk, durva neurológiai kórjele nem volt (2. ábra). Korai pszichomotoros fejlődése normális ütemú. Édesanyja mellről táplálja, félrenyelés, légzési tünetek nem alakultak ki. Jelenleg 22 hónapos, mozgásügyessége a korának megfelelő, kétoldali csontvezetéses hallókészülék (Baha 5) mellett beszédfejlődése is megindult. A 3. ábrán látható 22 hónapos korában.

\section{Módszer}

TCS gyanúja miatt a proband mintáját külföldi genetikai laboratóriumba (GENDIA; Antwerpen, Belgium) küldtük multigénpanel- (comprehensive hearing loss and deafness next generation sequencing panel) vizsgálat elvégzésére. Ennek során 181, hallásvesztéssel, süketséggel összefüggésbe hozott gén kódoló- és 'splice site' régiójának vizsgálata történt meg az újgenerációs szekvenálás (NGS) módszerével. A panelvizsgálat emellett tartalmazta a 181 gén deletio-duplicatio analízisét is. Az NGS során azonosított variánsok konfirmálására és a családtagok célzott mutációanalízisére intézetünk molekuláris genetikai laboratóriumában került sor Sanger-szekvenálással (4. ábra). Az amplifikációt általunk tervezett oligonukleotid-primerpárok segítségével (F: 5'-GTTG-

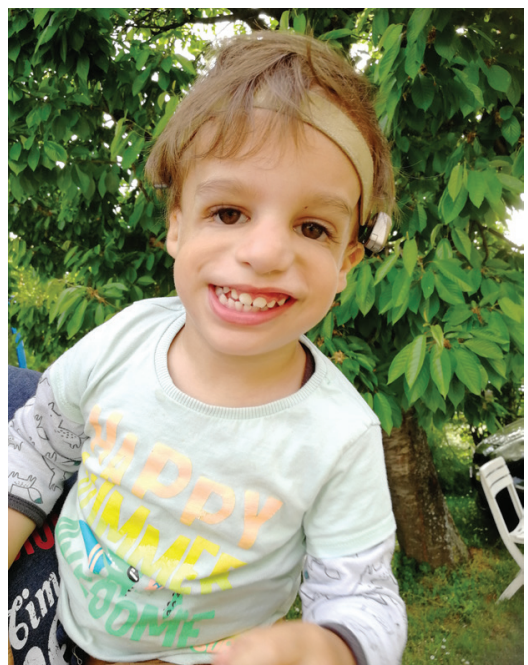

3. ábra A beteg 22 hónaposan (a fényképet a szülők beleegyezésével mutatjuk be)

TGATGGCTTCTGGTGG-3'; R: 5' - GAACCAGGTCTGGGTGTGTAG-3') SensoQuest Labcycler (SensoQuest GmbH, Göttingen, Németország) típusú PCR-készüléken kiviteleztük $59^{\circ} \mathrm{C}$ annealing hőmérsékleten. A vizsgálatot Applied Biosystems TM 3500 Genetic Analyzer típusú szekvenálókészüléken (Thermo Fisher Scientific Inc.; Waltham, MA, Amerikai Egyesült Államok), fluoreszcensen jelölt ddNTP-k segítségével végeztük.

\section{Eredmények}

AzNGSpanelvizsgálata TCOF1-gén(NM_001135243.1) egy 5 nukleotidot érintő deletióját azonosította heterozigóta formában (c.4369_4373delAAGAA). A deletio egy 'frameshift' mutáció, amely a fehérjeleolvasási keret eltolódását, ezáltal korai stopkodon kialakulását okozza (p.Lys1457Glufs*12); így csonkolt fehérje vagy csökkent mennyiségü mRNS képződhet az mRNS lebomlása miatt. A TCOFI: c.4369_4373delAAGAA variáns egy szakirodalomban ismert variáns, melyet korábban több más, TCS-ban érintett beteg esetében leírtak; a ClinVaradatbázisban patogén variánsként szerepel. A proband tüneteinek hátterében tehát a TCS klinikai diagnózisát az elvégzett genetikai vizsgálat alátámasztotta. A pedigrén ponttal jelölt családtagok célzott vizsgálata során a mutáció hordozása igazolódott (1. ábra). A korábban elhunyt, TCS-ban szenvedő családtag tárolt mintájában is kimutattuk a TCOFl-gén mutációját. A hordozósági szűrést genetikai tanácsadás keretében a nagykorú családtagoknak felajánlottuk. A beteg édesanyjának apai ágú, nagykorú férfi féltestvéréről (III/3., akivel eddig nem tartották a kapcsolatot, csak azt tudta a család, hogy egy fülkagylója van) kiderült, hogy a klinikai tünetek alapján ő is TCS-ás, a genetikai vizsgálatba azonban nem egyezett bele. 
$11 / 4$

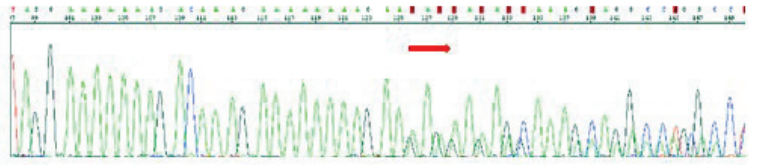

III/1

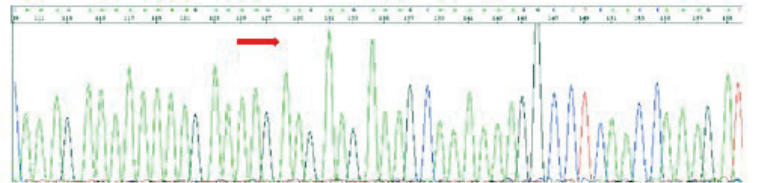

$\mathrm{III} / 2$

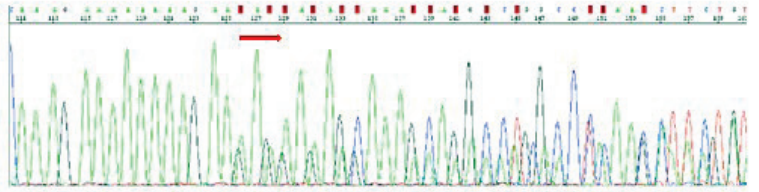

III/6

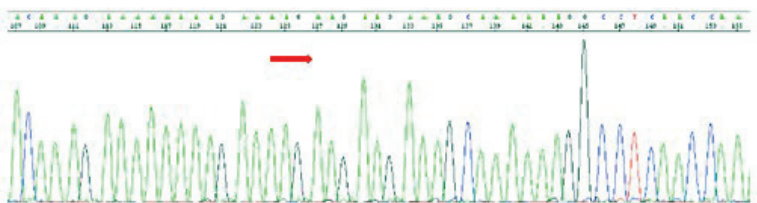

$\mathrm{III} / 7$
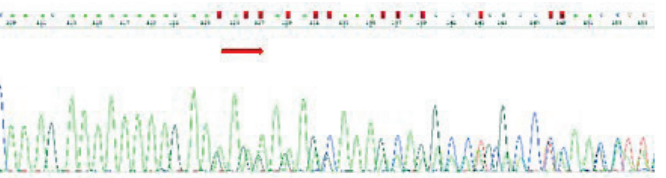

IV/3

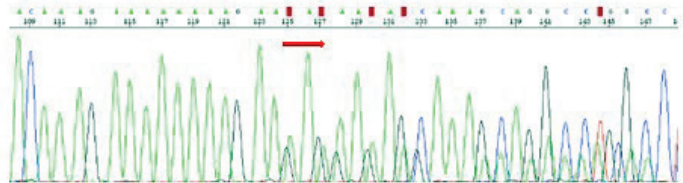

IV/7

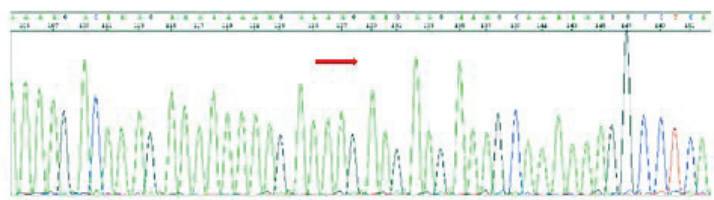

IV/8

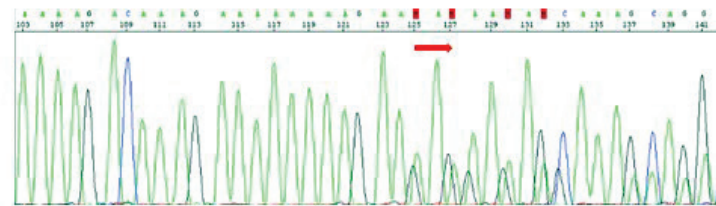

4. ábra

A TCOF-gén érintett szakaszának vizsgálata direkt szekvenálással. Az ábrán a vizsgálatban részt vevő családtagok elektroferogramja látható. A nyíl az érintett régiót jelöli

$T C O F=$ treacle ribosome biogenesis factor

\section{Megbeszélés}

A TCOFl-gén a treacle nevű nucleolaris foszfoproteint kódolja. Ez a fehérje a korai embrionális fejlődés során aktív, kritikus szerepet játszik az arc csontjainak és egyéb szöveteinek kialakulásában. A 'treacle' a nucleolusokban aktív, a riboszomális RNS (rRNS) előállításában vesz részt [10]. A rRNS segít az aminosavak múködőképes fehérjékké történő összeépítésében, ez elengedhetetlen a sejtek normálmúködéséhez és túléléséhez. A TCOF1gén eltérései $\mathrm{AD}$ módon öröklődnek. Az AD módon öröklődő betegségek egy kóros allél jelenlétében, azaz heterozigóta állapotban is manifesztálódnak. A felelős gének a 22 testi kromoszóma egyikén helyezkednek el. A betegség nóket és férfiakat egyaránt érint. Az érintettek 50\%-os valószínúséggel örökítik tovább utódaiknak a kóros gént. Egészséges szülők beteg gyermeke esetén diagnosztikai problémát okozhat, és megnehezíti a genetikai tanácsadást az új mutáció, a csökkent penetrancia és a változó expresszivitás jelensége. A domináns módon öröklődő betegségek többségében a szülők egészségesek, a betegség az utódoknak továbbadott egyetlen ivarsejtben létrejövő új mutáció következménye; ilyen esetben nem kell ismétlődési kockázattal számolni. Inkomplett penetrancia esetében a kóros gén jelen van a genomban, a klinikai képben azonban nem jelenik meg. A gén áthatolóképessége kifejezi, hogy az adott hibás gén a génhordozókban milyen százalékos gyakorisággal hozza létre a neki megfelelő klinikai tünetet. A változó expresszivitás a betegség különböző súlyossági fokozatait vagy eltérő formában való megjelenését jelenti, az azo- nos kóros gént hordozó családtagok klinikai tünetei rendkívül változatosak lehetnek.

A TCS esetében körülbelül 60\%-ban alakul ki a betegség új mutáció következtében, ilyen esetekben újabb gyermek vállalása esetén nem kell ismétlődési kockázattal számolni [11]. Az ivarsejtek mozaicizmusának következtében ritkán előfordulhat, hogy egészséges szülőknek több mint egy beteg gyermeke születik. Az érintettek 40\%-ában a mutáció azonban örökletesnek bizonyul.

Az NGS vizsgálatok elterjedésével lehetőségünk van a klinikailag felismerhető, jól ismert genetikai betegségek, mint a TCS molekuláris genetikai vizsgálatára, aminek fóleg az érintett családok genetikai tanácsadásában van jelentôsége. Esetünkben a család vizsgálata során az édesanyánál (III/2.) a proband esetében észlelt eltérést heterozigóta formában kimutattuk, tehát ő a TCS kialakulásáért felelős gén mutációját hordozza, bár klinikai tünetei nincsenek. A jelenség magyarázata az, hogy néha a hibás gén a fenotípusban nem kerül kifejeződésre. A nem teljes penetrancia következménye lehet, ha fenotípusosan egészséges embernek születik beteg gyermeke, mintha a hibás gén „átugorná” őt a családfán. Valójában a hibás gén jelen van, csak az expresszivitása nulla. Az AD öröklődésmenetet mutató eseteknél a szülő érintettsége esetén $50 \%$ valószínűsége van annak, hogy ismételt gyermekvállalás esetén beteg gyermek születik. Érdekes megfigyelés, hogy ebben a betegségben anyai érintettség esetén az utódok fenotípusa súlyosabb, apai érintettség esetén enyhébb a megelőző generáció fenotípusához képest. Ez az általunk vizsgált család esetében is jellemző. A proband két fiútestvére (IV/1. és IV/2.) fenotípusosan egészséges, csakúgy, mint az elhunyt családtag fia- 
talabb lánytestvére (IV/9.); esetükben hordozósági szưrésre a nagykorúság elérését követően lesz lehetőség.

A bemutatott családfa érdekessége, hogy bár $\mathrm{AD}$ öröklődésmenetet mutató betegség öröklődik a családban, a családfán nem az erre típusos, minden generációban megjelenő fenotípust látjuk az inkomplett penetrancia következtében. Míg csak egy érintett gyermek volt a családban, feltételeztük, hogy a betegség de novo mutáció következtében alakult ki. Amint a családfán látható, több családtag esetében kimutatható volt a TCOFl-gén mutációja annak ellenére, hogy klinikai tünetük nem volt. Ez megváltoztatja a genetikai tanácsadás menetét. Hiszen míg de novo mutáció esetében nem kell ismétlődési kockázattal számolni, egy szülő érintettsége esetén $50 \%$ valószínúsége van annak, hogy ismételt gyermekvállalás esetén beteg gyermek születik. A III/6. és a IV/7. családtagok esetében a célzott mutációanalízis negatív eredményt adott, így utódaik esetében a betegség kialakulásának kockázata az átlagpopulációéval megegyező.

A változó expresszivitás csakugyan megfigyelhető a bemutatott család esetében. Míg a proband tünetei mérsékeltek, másod-unokatestvére (IV/8.) a betegség következtében kialakult szövődmények következtében kisdedkorban exitált. Ugyanakkor a családban előfordul olyan érintett (III/3.) is, akinek nagyon enyhe tünetei vannak.

Esetbemutatásunk célja, hogy felhívjuk a figyelmet a genetikai vizsgálat elvégzésének fontosságára olyan, klinikailag jól felismerhető szindróma, mint a TCS esetén. Bár a betegség a klinikai kép alapján diagnosztizálható, az ismétlődés kockázatát csak úgy tudjuk pontosan meghatározni, ha a családtagok genotípusát, illetve az eltérés penetranciáját ismerjük. Így a családtagok gyermekvállalási szándéka esetén praenatalis vizsgálat elvégzésére tudunk vállalkozni.

Anyagi támogatás: Ez a munka a GINOP-2.3.2-15-201600039., valamint az EFOP-3.6.3-VEKOP-16-201700009. számú projekt támogatásával jött létre.

Szerzôi munkamegosztás: Zs. A.: A klinikai rész és a megbeszélés megírása. M. A. és Sz. A.: A módszerek és az eredmények megírása, a molekuláris genetikai vizsgálatok végzése és az eredmények kiértékelése. T. Á. és P. A. L.: A beteg vizsgálása. H. K.: A kézirat véleményezése és javítása. A cikk végleges változatát valamennyi szerző elolvasta és jóváhagyta.

Érdekeltségek: A szerzőknek nincsenek érdekeltségeik.

\section{Irodalom}

[1] Collins ET. Case with symmetrical congenital notches in the outer part of each lower lid and defective development of the malar bones. Trans Ophthalmol Soc UK 1900; 20: 190-192.

[2] Vincent M, Geneviéve D, Ostertag A, et al. Treacher Collins syndrome: a clinical and molecular study based on a large series of patients. Genet Med. 2016; 18: 49-56.

[3] Szakszon K. Treacher Collins syndrome. In: Oláh É. (ed.) Clinical genetics. [Treacher Collins-szindróma. In: Oláh É. (szerk.) Klinikai genetika.] Medicina Könyvkiadó Zrt., Budapest, 2015; pp. 512-513. [Hungarian]

[4] Marres HA. Hearing loss in the Treacher Collins syndrome. Adv Otorhinolaryngol. 2002; 61: 209-215.

[5] Vincent M, Collet C, Verloes A, et al. Large deletions encompassing the TCOF1 and CAMK2A genes are responsible for Treacher Collins syndrome with intellectual disability. Eur J Hum Genet. 2014; 22: 52-56.

[6] Dixon J, Edwards SJ, Gladwin AJ, et al. Positional cloning of a gene involved in the pathogenesis of Treacher Collins syndrome. Nat Genet. 1996; 12: 130-136.

[7] Dauwerse JG, Dixon J, Seland S, et al. Mutations in genes encoding subunits of RNA polymerases I and III cause Treacher Collins syndrome. Nat Genet. 2011; 43: 20-22.

[8] Sanches E, Laplace-Builhé B, Mau-Them FT, et al. POLR $1 B$ and neural crest cell anomalies in Treacher Collins syndrome type 4 . Genet Med. 2020; 22: 547-556.

[9] Lines MA, Huang L, Schwartzentruber J, et al. Haploinsufficiency of a spliceosomal GTPase encoded by EFTUD2 causes mandibulofacial dysostosis with microcephaly. Am J Hum Genet. 2012; 90: 369-377.

[10] Sakai D, Trainor AP. Treacher Collins syndrome: Unmasking the role of Tcofl/treacle. Int J Biochem Cell Biol. 2009; 41: 1229_ 1232.

[11] Dixon J, Ellis I, Bottani A, et al. Identification of mutations in TCOF1: use of molecular analysis in the pre- and postnatal diagnosis of Treacher Collins syndrome. Am J Med Gen. 2004; 127A: 244-248.

(Zsigmond Anna dr., Pécs, József A. u. 7., 7623 e-mail: zsigmond.anna@pte.hu)

A cikk a Creative Commons Attribution 4.0 International License (https://creativecommons.org/licenses/by/4.0/) feltételei szerint publikált Open Access közlemény, melynek szellemében a cikk bármilyen médiumban szabadon felhasználható, megosztható és újraközölhető, feltéve, hogy az eredeti szerző és a közlés helye, illetve a CC License linkje és az esetlegesen végrehajtott módosítások feltüntetésre kerülnek. (SID_1) 